\title{
Repatriation of Afghan refugees from Iran: a shelter profile study
}

\author{
Mitra Naseh $^{1 *}$ (D, Miriam Potocky ${ }^{1}$, Paul H. Stuart ${ }^{1}$ and Sara Pezeshk ${ }^{2}$
}

\begin{abstract}
One in every nine refugees worldwide is from Afghanistan, and Iran is one of main host countries for these refugees. Close to 40 years of hosting Afghan refugees have depleted resources in Iran and resulted in promoting and sometimes forcing repatriation. Repatriation of Afghan refugees from Iran to Afghanistan has been long facilitated by humanitarian organizations with the premise that it will end prolonged displacement. However, lack of minimum standards of living, among other factors such as private covered living area, can make repatriation far from a durable solution. This study aims to highlight the value of access to shelter as a pull factor in ending forced displacement, by comparing Afghan refugees' housing situation in Iran with returnees' access to shelter in Afghanistan. Findings suggest that over $80 \%$ of surveyed Afghans in our study had access to private durable covered living space with minimum standards of living in Iran. The documents retrieved in our systematic literature review show that access to similar standards was between 30 and $73 \%$ among Afghan returnees. Results of our analysis call for reevaluation of repatriation as a durable solution for Afghan displacement in the absence of decent shelter conditions, and highlight a need for incorporation of shelter assistance programs into repatriation plans.
\end{abstract}

Keywords: Shelter, Afghan refugees, Afghan returnees, Repatriation

\section{Introduction}

In the mid-1970s, when conflict and political disputes started in Afghanistan, Iran opened its borders and sheltered Afghan refugees on prima facie basis (Margesson 2007). This means that being an Afghan was sufficient evidence for receiving protection in Iran. Conflict and instability in Afghanistan continued with the Communist coup and the Soviet Union's invasion in 1979 (Margesson 2007; Ruiz 2004). During this period, which coincided with the Iranian Islamic Revolution, Afghans were eligible to receive refugee status at the borders of Iran as religious immigrants (Moravej 2014). From the religious perspective of the new government in Iran, sheltering Afghans was considered a help for Muslim brothers and sisters (Marchand et al. 2014). Until 1992, Iran greeted Afghans with open borders and granted them indefinite permission to stay (Margesson 2007; Rajaee 2000). However, after 1992, Iran gradually put strategies in place to limit the number of new refugee entries at its borders, encouraging

\footnotetext{
* Correspondence: mahma024@fiu.edu

${ }^{1}$ School of Social Work, Robert Stempel College of Public Health and Social Work, Florida International University, Miami, USA

Full list of author information is available at the end of the article
}

and sometimes pressuring Afghans into voluntary repatriation. This change in policy was partly due to associated financial and security costs of maintaining nearly two million refugees in the aftermath of Iran's baby boom, the expensive war with Iraq, and economic sanctions (Farrokhi and Rahmati 2010; Rajaee 2000; Rostami-Povey 2008).

Voluntary repatriation to home countries, resettlement in a third country, and local integration within the country of first asylum are the defined durable solutions by the United Nations High Commissioner for Refugees (UNHCR) to end refugee displacement (UNHCR 2016a). Voluntary repatriation is the main durable solution for the majority of refugees, as countries of first asylum are usually reluctant to allow integration, and designated quotas by countries accepting resettlement worldwide are very limited. For instance, on the global scale, only 23,000 refugees were locally integrated and naturalized within countries of first asylum and 189,300 refugees were admitted for resettlement in a third country, while over two and a half times this number repatriated to their home countries in 2016 (UNHCR 2017a). For refugees with prima facie status, such as Afghans in Iran, voluntary repatriation is commonly expected and usually 
enforced as soon as the country of origin is recognized "safe" for return (Jacobsen 2005). However, the definition of "safe" is ambiguous and commonly misinterpreted to protect the interests of those in power.

Organized efforts by the Iranian government to facilitate the repatriation of Afghans began in late 1992 (Marchand et al. 2014). As far as Iran was concerned, the Soviet war that created the Afghan refugee crisis was over, and Afghanistan was "safe" enough for the return of refugees (Qadeem 2005). To facilitate and encourage repatriation of Afghans, Iran joined forces with the government of Afghanistan and the UNHCR in the framework of the Tripartite Commission (Adelkhah and Olszewska 2007; Marchand et al. 2014; Rajaee 2000). Under the operation of this commission, the UNHCR would provide an assistance package consisting of USD25 in cash, $50 \mathrm{~kg}$ of wheat, and a floor mat for documented Afghan households who would give up their refugee status in Iran and return to Afghanistan (Rajaee 2000).

Beginning in 1993, Iran started to put policies in place to make the country a less desirable destination for Afghan refugees. For instance, the Iranian government started to grant temporary registration cards to Afghan refugees instead of indefinite permission (Margesson 2007). These temporary registration cards confined Afghans to residence in refugee settlements or designated rural or urban areas (Rostami-Povey 2008). Starting in 1995, Iran closed its border with Afghanistan and stopped accepting newly arrived Afghans at the border on a prima facie basis (Garakani 2009; Marchand et al. 2014). In the course of the succeeding years, Afghans have had to prove owning a well-founded fear of persecution to earn a refugee status in Iran. Moreover, after 1995, Iran increasingly enacted measures to control refugees' access to free or subsidized resources such as education, energy, and health services (Garakani 2009; Marchand et al. 2014; Margesson 2007; Rajaee 2000; Rostami-Povey 2008).

Despite the above-discussed changes in policies, Iran remained one of the essential destinations for Afghan refugees, as their home country continued to struggle with wars and conflicts. Besides the geographic proximity to Iran, the similarity in the language and culture of the country makes it a desirable destination for Shia Muslim and Dari/Farsi speaking Afghans such as Hazaras (Azizi et al. 2017). Shortly after the Soviet Union withdrew from Afghanistan, the Taliban, an Islamic fundamentalist political movement with a repressive interpretation of Islamic law, took control of parts of Afghanistan (Ruiz 2004). Their austere interpretation of Islamic law raised more conflict and forced many Afghans to flee the country (Qadeem 2005). By 1996, the Taliban had assumed control of Afghanistan, except for $20 \%$ in the north, which was controlled by the Northern Alliance who opposed the oppressive Taliban rules (Qadeem 2005; Sharp et al. 2002). Due to their financial needs and extreme political views, the Taliban sheltered the terrorist group al-Qaeda, leading to the start of another war in Afghanistan in 2001 (Sharp et al. 2002). In October 2001, Operation Enduring Freedom (OEF), supported by Special Operations Forces from all three USA military services and coalition partners, attacked Afghanistan to remove the Taliban from power (Ender 2010). After massive aerial bombardment began as part of the OEF attack, one in every four Afghans was already living as a refugee in another country (Ruiz 2004).

In the same year that the USA-led attack on Afghanistan started, Iran introduced an integrated registration system for refugees called Amayesh (Adelkhah and Olszewska 2007). Registration cards replaced all other previously issued documents for Afghans and became the only valid refugee documentation in Iran (UNHCR 2014). Through Amayesh cards, Iran limited how long refugees could stay in the country and where they could reside (Barr and Sanei 2013). The Bureau for Aliens and Foreign Immigrants Affairs (BAFIA), which has carried out Amayesh registration schemes annually since 2010, is the entity in charge of refugees in Iran (UNHCR 2014). According to the Country of Origin Information Centre report on Afghan citizens in Iran, refugees had to pay up to USD200 for municipal tax and USD15 to renew their refugee status (Landinfo 2012). Beginning in 2007, the government of Iran placed additional restrictions on issuing any new Amayesh cards for undocumented refugees or newly arrived Afghans, and stopped new refugee registration (Barr and Sanei 2013). Since 2007, only previously registered Afghans with valid Amayesh cards can continue renewing their cards and live as documented refugees in Iran. Lack of documentation places Afghans at risk of arrest and deportation to Afghanistan (Koepke 2011).

Besides enacting restrictive regulations for refugees, Iran in collaboration with UNHCR continued to facilitate voluntary and sometimes forced repatriation of Afghans. In 2002, while the USA-led war was ongoing in Afghanistan, Iran signed the tripartite agreement with Afghanistan and the UNHCR to expedite the repatriation of millions of Afghans (Barr and Sanei 2013). Additionally, in 2012, Iran joined a new initiative called the Solutions Strategy for Afghan Refugees to Support Voluntary Repatriation, Sustainable Reintegration and Assistance to Host Countries to advance the repatriation of Afghans (Barr and Sanei 2013).

The war in Afghanistan officially ended in 2014. However, large numbers of Afghans remained in protracted refugee situations in Iran. Many Afghans are second-generation refugees in Iran. According to the data collected in 2005, over $30 \%$ of the documented Afghans were second-generation, 
meaning that they arrived as children or born in Iran (Abbasi-Shavazi et al. 2008). According to UNHCR's latest global trend report, $11 \%$ of refugees worldwide are from Afghanistan and around $40 \%$ of this population resides in Iran (UNHCR 2017a, b, c). Iran hosts the largest urban refugee population in the world; 951,142 documented Afghan refugees live in this country, and around 97\% of them live in urban and semi-urban areas (UNHCR 2015a, b). Besides documented refugees, there are between half a million to two million undocumented Afghans in Iran who either arrived after the restriction of new Amayesh cards or could not afford to renew their cards (Azizi et al. 2017; Koepke 2011; Marchand et al. 2014; Milani 2006; Rajaee 2000; Scalettaris 2010).

As a result of the efforts to encourage and sometimes pressure Afghans into repatriation, over 4.2 million Afghans returned or were deported to Afghanistan from Iran between 1992 and 2010 (Abbasi-Shavazi et al. 2008; Koepke 2011; Majidi 2017; Marchand et al. 2014). UNHCR reports on documented refugees show that 920,161 Afghans returned from Iran between 2002 and 2014 (UNHCR 2015a). For the past decade, Afghanistan has consistently been one of the main countries of origin receiving returnees globally (Majidi 2017). In 2011, around one-third of the population in Afghanistan were returnees (Loschmann et al. 2015). Despite their large population, the living situation of Afghan returnees is one of the most understudied areas in the forced migration field (Majidi 2017).

For returnees, access to minimum standards of living in Afghanistan could be a cornerstone of stability and a key to successful repatriation. Access to minimum standards of living could also be an important pull factor to initiate or encourage the return. Among minimum standards of living, access to a covered living area is a fundamental human need and an essential element in the provision of protection, dignity, and identity for returnees (Babister and Kelman 2002). Moreover, access to a covered living area could be an essential element for households' livelihood and socio-economic development (Babister and Kelman 2002; Crea et al. 2017; Loschmann et al. 2015). In the harsh winters and hot summers of Afghanistan, access to shelter could be a crucial factor for survival. Therefore, lack of access to shelter for the large population of Afghan returnees could be a cause for concern, and an important factor to consider in repatriation strategies. To explore this concern, our study aims to document the shelter profile of Afghan refugees in Iran and returnees in Afghanistan. In this context, this study explores the housing situation of Afghan refugees in Iran and compares it with reported accommodation conditions of Afghan returnees.

\section{Conceptual framework}

The conceptual model of the study and our definition of shelter or housing is grounded in the minimum standards for "covered living space" and "design" as described in the Sphere Project (2011) handbook. The Sphere Project handbook is a guideline that defines minimum standards in humanitarian response. Although the handbook has no time limitation, it is mainly focused on disaster-affected populations. While Afghan returnees could be considered a disaster-affected population in the case of secondary displacement, refugees in Iran are in a protracted and stable situation. Therefore, the listed minimum standards by the Sphere Project handbook could be far from an ideal framework for refugee housing in Iran. However, the listed minimum standards by this handbook provide a minimum baseline for comparison between Afghan refugees in Iran and returnees in Afghanistan.

Five indicators were defined in this study to assess housing situations based on the Sphere Project (2011) handbook (1) minimum covered area of $3.5 \mathrm{~m}^{2}$ per person; (2) households' access to a private covered cooking area (kitchen); (3) households' access to a private latrine; (4) households' access to electricity; and (5) households' access to piped water (Table 1). These five indicators were defined based on the first and third indicators under the Sphere Project's minimum standards for a "covered living space," and the fifth indicator of the Sphere Project's minimum standards in "design."

Due to limitation of data, indicators related to privacy and livelihood activities under the Sphere Project's minimum standards for a "covered living space" and four of the indicators related to Sphere Project's minimum standards in "design" were excluded in our study.

\section{Methodology}

\section{Data and information sources}

This study is based on two information sources: (1) a descriptive analysis of cross-sectional data collected from Afghan refugees in Iran in 2011 (Ahmadinejad 2011), and (2) a systematic literature review in English and Farsi in regard to the housing situation of Afghan refugees in Iran and returnees in Afghanistan.

The cross-sectional data was utilized to report on the housing situation of Afghan refugees in Iran. This dataset was collected in 2011 through convenience sampling and structured interviews with heads of Afghan households in the capital cities of the five most refugee-populated provinces in Iran: Tehran, Khorasan-e Razavi, Isfahan, Kerman, and Fars. Available statistics from 2011 show that more than half of the documented refugees in Iran lived in provinces of Tehran, Khorasan-e Razavi, and Isfahan (Azizi et al. 2017). Moreover, according to the Amayesh registration scheme carried out in 2011, Kerman and Fars province together host around $15 \%$ of the documented 
Table 1 Housing indicators

\begin{tabular}{|c|c|}
\hline The sphere project indicators & Proxy indicators for this study \\
\hline \multicolumn{2}{|l|}{ Indicators for covered living space } \\
\hline 1. The initial covered floor area per person is at least $3.5 \mathrm{~m}^{2}$ & 1. Per head covered area of $3.5 \mathrm{~m}^{2}$ \\
\hline $\begin{array}{l}\text { 2. The covered area enables safe separation and privacy between the sexes, between different } \\
\text { age groups, and between separate families within a given household as required }\end{array}$ & Excluded due to lack of data \\
\hline 3. Essential household activities can be carried out within the shelter & $\begin{array}{l}\text { 2. Access to a private covered cooking } \\
\text { area (kitchen); } \\
\text { 3. Access to a private latrine; }\end{array}$ \\
\hline 4. Key livelihood support activities are accommodated where possible & Excluded due to lack of data \\
\hline \multicolumn{2}{|l|}{ Indicators for design } \\
\hline $\begin{array}{l}\text { 1. The design of the shelter and the materials used are familiar where possible and culturally } \\
\text { and socially acceptable }\end{array}$ & Excluded due to lack of data \\
\hline $\begin{array}{l}\text { 2. The repair of existing damaged shelters or the upgrading of initial shelter solutions } \\
\text { constructed by the disaster-affected population is prioritized }\end{array}$ & Excluded due to lack of data \\
\hline $\begin{array}{l}\text { 3. Alternative materials required to provide temporary shelter are durable, practical, and } \\
\text { acceptable to the affected population }\end{array}$ & Excluded due to lack of data \\
\hline $\begin{array}{l}\text { 4. The type of construction, materials used, and the sizing and positioning of openings provides } \\
\text { optimal thermal comfort and ventilation }\end{array}$ & Excluded due to lack of data \\
\hline $\begin{array}{l}\text { 5. Access to water supply sources and sanitation facilities, and the appropriate provision of } \\
\text { rainwater harvesting, water storage, drainage, and solid waste management, complement the } \\
\text { construction of shelters }\end{array}$ & $\begin{array}{l}\text { 4. Access to electricity; } \\
\text { 5. Access to piped water; }\end{array}$ \\
\hline $\begin{array}{l}\text { 6. Vector control measures are incorporated into the design and materials are selected to } \\
\text { minimize health hazards }\end{array}$ & Excluded due to lack of data \\
\hline
\end{tabular}

Source: The Sphere Project (2011)

refugees in Iran. Sixteen university-educated and local Afghan refugees, who were the recipients of the Albert Einstein German Academic Refugee Initiative Fund in the above-mentioned provinces, conducted the interviews. Interviewers were instructed to fill the questionnaires in refugee-populated communities by starting from the first house in the area and approaching every fifth house to complete a maximum number of 150 questionnaires (Ahmadinejad 2011). The data were collected through 45-min structured interviews with the heads of the households, using an adapted version of the Statistical Center of Iran (2010) questionnaire for measuring expenditures and income. During these structured interviews, each household head provided information about every member of the household, resulting in a sample size of 2034 households and 10,889 individuals.

The systematic literature review was conducted to report on Afghan returnees' access to shelter in 2011, trends and progresses made since, and available shelter assistance programs and interventions for Afghan returnees. The review was conducted online, in English and Farsi, and in three major social science databases: Web of Science Core Collection, PsycInfo, and Google Scholar. The search was conducted on 4 May 2018 using keywords related to "returnee," "refugee," "shelter," "Afghan," and "Iran." The reference lists of the retrieved related documents, and the online archive of the Human Rights Watch reports, UNHCR website, International
Organization for Migration (IOM) publications, World Bank country level data, and Norwegian Refugee Council (NRC) resources were also reviewed.

\section{Analyses}

Access of Afghan refugees to the five defined proxy indicators for shelter was calculated using our secondary cross-sectional dataset and descriptive statistics analyses with Stata software version 14 (StataCorp 2015). The minimum per head covered living area was calculated by dividing the reported total area of living to total number of household members. Access to a private covered cooking area, private latrine, and piped water was calculated based on the self-reported data by heads of the households (private access, shared access, no access) to kitchen, toilet, and piped water. Access to electricity was not recorded in our dataset; therefore, we used the World Bank country level data on access to electricity in 2011 in Iran (The World Bank 2017). Through our systematic literature review we retrieved information about Afghan returnees' access to the five defined proxy indicators for shelter.

\section{Results}

Study findings are presented under three headings: (1) demographic characteristics of the surveyed Afghan refugees in Iran and their housing situation based on the conceptual framework of the study; (2) Afghan returnees' 
general housing situation in 2011 and their shelter profile based on the conceptual framework of the study; (3) comparison between shelter indicators for surveyed refugees in Iran and retrieved information about returnees in Afghanistan; (4) and review of the trends since 2011.

\section{Afghan refugees' housing in Iran}

The utilized cross-sectional dataset in this study constitute the data of 2034 Afghan households, out of which 84.3\% (1715 households) had valid Amayesh cards and 15.7\% (319 households) were undocumented. Around $83 \%$ (1687 households) of the sample resided in urban and semi-urban areas, around 9.5\% (194 households) in colonies, and $7.5 \%$ (153 households) in government-run settlements (camps). Around 20\% (405 households) of the surveyed households were in Tehran, around 19\% (394 households) were in Khorasan-e Razavi, around $18 \%$ (365 households) were in Isfahan, around 20\% (400 households) were in Kerman, and around 23\% (470 households) were in Fars province. Average years of residency in Iran among the surveyed households was 20.1 $(\mathrm{SD}=8.9)$ years, ranging between 1 month and 50 years. Average years of residency in Iran were lower among Afghans in Tehran and Fars province, and those residing in colonies and urban and semi-urban areas. Average age of the heads of the households was $43(\mathrm{SD}=13.3)$, and around 95\% of them (1924 heads of households) were born in Afghanistan and the rest were born in Iran or other countries. The majority of the interviewees were Hazara (67\%, 1361 households), around 14\% (292 households) were Pashtun, around 6.2\% (125 households) were Tajik, and the rest were of other ethnicities. Average household size was 5.3, with the minimum household size of one to a maximum of 19 members.

Among the surveyed Afghan refugee households in our sample, $98.5 \%$ had access to a private durable covered living space (Table 2). More specifically, 80.7\% (1640 households) lived in rental properties, 8.2\% (166 households) owned their houses, 5.9\% (120 households) lived in refugee settlements, $2.7 \%$ (55 households) were guards and lived in guardhouses, and 1.1\% (22 households) lived and worked on construction fields. Only $1.5 \%$ (30 households) of the surveyed refugee households in Iran did not have access to a private durable covered living space, as they lived with extended family members or friends. No one in our sample reported living in temporary shelters or uncovered accommodation settings. Access to rental properties and house ownership was very similar among documented refugees and undocumented Afghans in our sample, yet undocumented Afghans were more likely than documented refugees to live in guardhouses $(4.7 \%$ for undocumented and 2.33 for documented), live and work on construction fields (3.1\% for undocumented and $0.7 \%$ for documented), or live with their extended family members or friends $(3.5 \%$ for undocumented and $1.2 \%$ for documented). Chances for refugees to own a house was considerably higher among refugees living in Khorasan-e Razavi (35.3\%) compared to Afghans living in other provinces (less than $2 \%$ in our sample. Moreover, all refugees who owned a house lived in Iran at least for 10 years.

The average accommodation area for an Afghan refugee household with an average 5.3 members was $78.2 \mathrm{~m}^{2}$. The per capita covered accommodation area was larger than $3.5 \mathrm{~m}^{2}$ for most (around 96\%) of the surveyed households (Table 2). Access to minimum 3.5 square per capita covered accommodation area was only slightly different between documented (around 96\%) and undocumented (around 97\%) Afghans. The majority of households with a covered area of less than $3.5 \mathrm{~m}^{2}$ lived in settlements (42\%), resided in Kerman (68\%), and lived with extended family members and friends (45\%, 34 households).

Nearly 84\% (1705 households) of the surveyed Afghan refugee households in Iran had access to a private kitchen, over $82 \%$ (1676 households) had access to a private latrine, and over 98\% (2002 households) had access to piped water (Table 2). Access to a private kitchen, a private latrine, and piped water was slightly higher among documented refugees compared to undocumented Afghans (85 versus 75\%; 83 versus $77 \%$;

Table 2 Comparison of Afghan refugees' and returnees' housing and standards of living

\begin{tabular}{lll}
\hline Minimum standards of housing & Access level of refugee households in Iran ${ }^{\text {a }}$ & Access level of returnees in Afghanistan $^{b^{b}}$ \\
\hline Access to a private durable covered living space & Over 98\% & Around 35\% \\
Access to minimum per head covered area & Over $96 \%$ & Around 50\% \\
Access to a private covered cooking area & Over 83\% & No data \\
Access to a private latrine & Over 82\% & $29.90 \%$ \\
Access to electricity & Over 99\% & $61.51 \%$ \\
Access to piped water & Over 98\% & $72.60 \%$
\end{tabular}

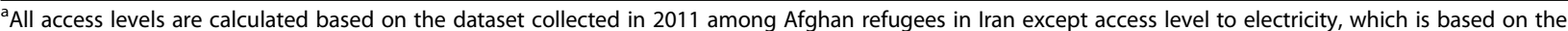
World Bank's country level data in 2011

${ }^{b}$ Access to a private durable covered living space and minimum per head covered area are based on the IOM baseline mobility assessment report (2017) in Nangarhar, Kunar, and Laghman provinces in Afghanistan; access to private latrine in 2011 is based on the WHO and UNICEF (2017) report; access to electricity in 2011 is based on the World Bank's country level data (2017); and access to piped water in 2011 is based on the Global Economy (2018) website 
and 99.5 versus $98 \%$ respectively). The majority of the household members without access to a private kitchen, latrine, or piped water lived with extended families and friends or lived in rental properties. Access to a private kitchen or a private latrine was considerably lower among Afghans living in settlements (46 and 25\%) compared to those living in urban and semi-urban areas $(88$ and $88 \%$ ) or colonies (78 and $80 \%$ ). Access to electricity was over $99 \%$ in 2011 in Iran, and the same level of access was considered for Afghan refugees in this study (Table 2).

\section{Returnees' housing in Afghanistan}

Nangarhar, Kandahar, Nimroz, and Herat province are the main points of entry for returnees in Afghanistan. Although Kabul is not a border province, it is the second largest province receiving returnees after Nangarhar. For returnees from Iran, Herat, Nimroz, and Kabul are the main destinations. Post-arrival humanitarian assistance is available in these provinces, but humanitarian organizations are more active in Nangarhar and Kandahar. For instance, IOM assisted $92 \%$ of the undocumented Afghans from Pakistan in Nangarhar in 2017, but only assisted 5\% of the undocumented Afghans from Iran in Nimroz (Kamminga and Zaki 2018). Studies and reports on Afghan returnees in Herat and Nimroz provinces are also scarce. One reason for this gap in the literature is that the population of returnees from Iran is considerably lower than returnees from Pakistan. Another reason is that returnees from Iran tend to live among host communities, as they used to in Iran, while returnees from Pakistan are more likely to live separately from local communities, as they lived mainly in camps in Pakistan.

Few Afghan returnees own property in Afghanistan and the majority live in rented houses upon return (Kent et al. 2017). In a study conducted by UNHCR, lack of land was the main concern of more than half of the returnees, and lack of shelter was the main concern of over $15 \%$ of the returnees (UNHCR 2017b). One of the reasons for lack of access to shelter for Afghan returnees is that years of conflict destroyed many properties and changed land ownerships. Returnees are either unable to reclaim their properties or do not own land; therefore, they have to rent. However, the current emphasis on Afghan repatriation created an influx of returnees, and impacted Afghanistan's housing market by creating high and unaffordable rent costs (IOM 2017). Only in 2017, around 59,000 refugees and nearly 500,000 undocumented Afghans returned to Afghanistan (Majidi 2017). Consequently, returnees are forced to rent houses in remote areas that have lower rates, share a house with other families to make rents more affordable, live in tents or sub-standard shelters, borrow money to afford rents, rely on child labor to increase income, or live in open areas (IOM 2017; Samuel Hall et al. 2018).

High rent costs in recent years have led to the eviction of many returnees from their residences, forcing them to live in tents, half-constructed buildings, or in the open air (IOM 2017; Kent et al. 2017). In some cases, returnees are forced to move constantly in search of more affordable housing (Samuel Hall et al. 2018). An IOM baseline mobility assessment report (2017) shows that rents have nearly doubled between mid-2016 and March 2017 in Nangarhar province in Afghanistan, and prices are expected to further increase if the influx of returnees continues. This assessment, which was conducted in Nangarhar, Kunar, and Laghman, estimates that around $14 \%$ of the returnees lived in tents or open areas, and only $35 \%$ had access to a private durable covered living space (IOM 2017). This assessment also indicates that more than $50 \%$ of returnees in these three provinces live with families or friends (IOM 2017). Another survey conducted by the IOM in Nangarhar province shows that up to $40 \%$ of the Afghan returnees lived in open areas or semi-constructed buildings (IOM 2016). A study by the United Nations Office for the Coordination of Humanitarian Affairs (UNOCHA) and the NRC found similar results and reports that hundreds of Afghan returnees live under open skies (Simpson et al. 2017).

Through our systematic search, we found no data on minimum per head covered area of living for Afghan returnees, but living in overcrowded shelters was evident (IOM 2017; Simpson et al. 2017). Unable to own or reclaim properties in Afghanistan, large numbers of returnees are forced to live with families and friends or in overcrowded settlements due to high costs of rent (Assessment Capacities Project 2016; IOM 2017; Simpson et al. 2017). It has been estimated that in 2009, around $80 \%$ of the population in Kabul, including returnees, lived in squatter settlements (Schmeidl 2009).

We were unable to find data on Afghan returnees' access to a kitchen. However, we estimated access to electricity and piped water based on the World Bank country level data and the Global Economy website. According to these sources, access to electricity was $61.51 \%$ in 2011 and increased to 84.1 in 2016 (The World Bank 2017). Moreover, access to drinking water in urban areas was $72.6 \%$ in 2011 and improved to $78.2 \%$ in 2015 (The Global Economy 2018). Nevertheless, lower levels of access to piped water were reported in small-scale studies at the provincial level. For instance, IOM baseline mobility assessment report in Nangarhar province shows that around $90 \%$ of the Afghans, including returnees, did not have access to tap water (IOM 2017). The same report reveals that in Laghman province lack of access to piped water forced returnees to use wells, natural water 
sources, and water tankers (IOM 2017). Country level access to improved sanitation including private latrine was $29.90 \%$ in 2011 and increased to 31.90 in 2015 (WHO and UNICEF 2017) (Table 2).

\section{Comparison}

Based on our 2011 data, the housing situation of Afghan refugees in Iran was better across all five reviewed indicators compared to returnees' situation in Afghanistan (Table 2). Access levels depicted in Table 2 should be interpreted with care as there was variation in sampling methods, locations, and target population of the resources. Refugees' access level to four out of the five defined indicators in Iran was calculated based on a cross-sectional survey in the five most refugee populated provinces of Iran in 2011, while access to electricity was estimated based on a country level data. Similarly, access to a latrine, piped water, and electricity among returnees in Afghanistan was estimated based on the country level data and might not exactly depict returnees' situation. Data on access to a private durable covered living space and minimum per head covered area was extracted from studies in Nangarhar, Kunar, and Laghman provinces. These three provinces are mainly receiving returnees from Pakistan and might not reflect the situation of returnees from Iran. However, since a similar data was not available for Herat or Nimroz, the main points of entry for returnees from Iran, these access levels were reported to provide a baseline for comparison (Fig. 1).

\section{Trends}

Our systematic search on trends in housing situation of Afghan refugees in Iran after 2011 found no indication of homelessness. However, difficulty in affording shelter by the most vulnerable groups, and a need to repair and upgrade in refugee resettlements, was indicated in the
NRC Factsheet and UNHCR portfolio of projects reports on Solution Strategy in Iran (NRC 2017; UNHCR 2014, 2015a). Most of the refugee settlements in Iran were built before the 1980s and need major upgrades. Humanitarian organizations including NRC and UNHCR have active construction projects for rehabilitation of infrastructures in these settlements. There are 20 settlements in Iran, and around 3\% of the documented refugees live in these settings (UNHCR 2015a). The findings on low standards of housing in settlements were in line with our descriptive statistic results from 2011. Our systematic search did not find any data on access to a private durable covered living space, average per capita covered accommodation area, access to a private kitchen, latrine, or piped water among Afghan refugees in Iran after 2011.

Likewise, we were unable to find a comprehensive report or study on returnees' access to the five reviewed minimum standards of shelter after 2011 in Afghanistan. However, in recent years, small-scale reports and studies show similar trends in lack of access to shelter among returnees (Barr and Sanei 2013; Majidi 2017; Simpson et al. 2017; UNHCR 2017c). In a quantitative survey conducted in Herat, Kabul, Kandahar, Kunduz, and Nangarhar provinces in Afghanistan, around $45 \%$ of the Internally Displaced People (IDP) were returnees (Majidi 2017). There is no clear statistics on the number of returnees who are forced to secondary displacement due to lack of access to shelter, but reports and studies confirm that housing is a major challenge. For instance, lack of a decent land, housing, or shelter was the main challenge cited by $79 \%$ of the interviewed returnee-IDPs in five provinces of Afghanistan (Majidi 2017). In Majidi's study (2017), access to housing was the third leading factor, after security and job opportunities, to encourage IDPs to move. Although access to a private latrine, electricity, and piped water has increased in

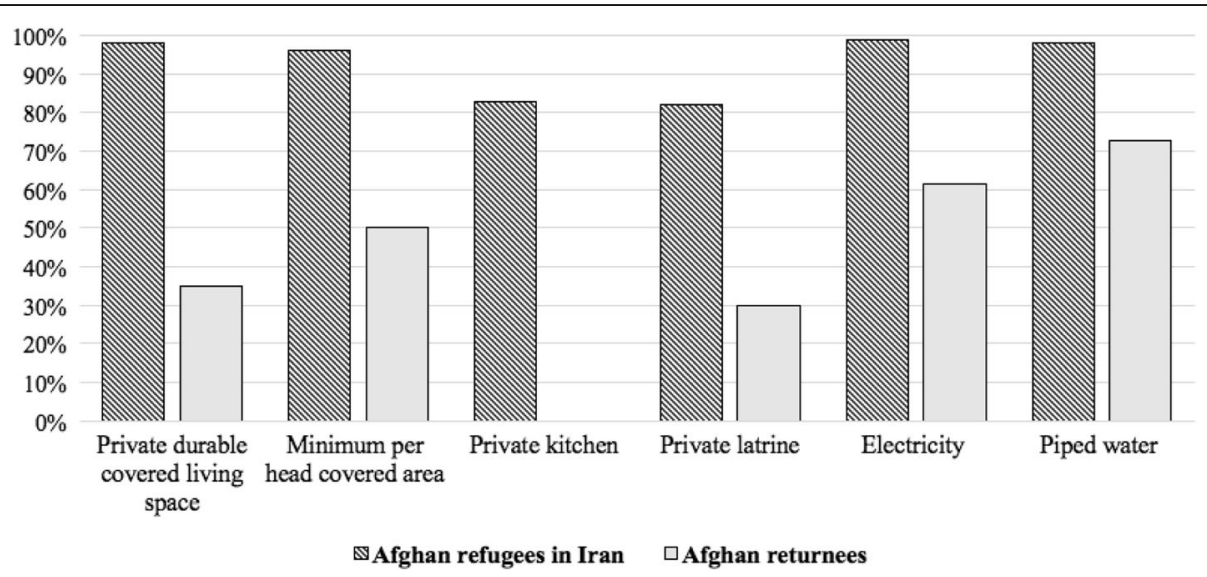

Fig. 1 Comparison of Afghan refugees' and returnees' housing and standards of living 
Afghanistan since 2011, all access levels are still lower than refugees' access to these services in Iran in 2011.

\section{Shelter assistance programs for returnees}

As part of the efforts to facilitate repatriation and reintegration of Afghans, shelter and land assistance programs have been implemented in Afghanistan by different humanitarian and governmental organizations. Land Allocation Scheme (LAS) might be one of the most important interventions by the government in this field. The LAS initiative started in 2005 by the Ministry of Refugees and Repatriation in Afghanistan to allocate intact governmental lands to returnees and IDPs (Macdonald 2011). Under this initiative, landless Afghan returnees can apply to receive temporary land ownership deeds. By 2013, over 13,700 land plots were distributed to landless returnees or IDPs through LAS (Majidi 2013). However, several reports indicated that the program struggled to deliver on its pledge. It has been reported that a considerable number of beneficiaries of the LAS program have sold their lands on the black market, or handed them to friends or family members, and moved to the outskirts of Afghanistan's capital city or left the country entirely (Majidi 2013; Rao and Turkstra 2014). The remote locations of the allocated lands, lack of access to livelihood activities, and basic standards of living such as piped water, latrines, primary education, and health care are among the main reported reasons for abandonment of the allocated lands (Majidi 2013; Rao and Turkstra 2014). Some believe that LAS is a form of exclusion and discrimination as recipients are forced to live on deserted and remote locations (Majidi 2013). Out of the 38,000 recipients of the plots in 2011, only $24 \%$ moved in and lived in the allocated lands (Special Inspector General for Afghanistan Reconstruction [SIGAR] 2015). Corruption and lack of transparency in allocation process was also reported as a main challenge for LAS (The International Bank for Reconstruction and Development 2017). In 2011, only $14 \%$ of the applicants received land plots, and several instances of corruption was reported (SIGAR 2015). More importantly, lands are only allocated in returnees' area of origin, but over $45 \%$ of returnees live in areas other than those of their origin (UNHCR 2015b).

With regard to shelter assistance programs, provision of emergency and durable shelters has been more common in Afghanistan. Emergency shelters are easily set up and used for short periods of time, usually less than 1 year. Different types of tents fall under this category of shelters. Durable shelters are constructs that provide durable covered living areas and can last an average of 10 years or more (UNHCR 2016b). Houses built with common materials such as bricks or mud fall in this category. Transitional shelters are the third category of shelters, which are more durable than emergency shelters and usually last for two to a maximum of 5 years (UNHCR 2016b). Prefabricated shelters including Refugee Housing Units (RHU) fall in this category.

In 2011, UNHCR and NRC were leading the main durable shelter assistance programs in Afghanistan. The UNHCR shelter assistance program consisted of a cash assistance (between USD50 and USD200), donation of some construction materials, provision of doors and windows, donation of roofing beams, and supervision for construction of an average $32 \mathrm{~m}^{2}$ durable mud house in 2 months (The Maastricht Graduate School of Governance [MGSOG] and Samuel Hall 2012). This program provided 220,000 units of shelter between 2002 and 2012 for Afghans, with an estimated cost of USD1800 to USD2000 per unit (MGSOG and Samuel Hall 2012). The NRC shelter assistance program was a predominantly cash-based and community driven program that offered construction of one- and two-room durable shelters with private latrines for Afghans in Kabul, Kunduz, Nangarhar, Laghman, Kunar, and Khost provinces in Afghanistan (NRC 2015). If Afghan returnee households could provide unskilled labor and construction materials, worth between 30 and $40 \%$ of the NRC's cash assistance, then this organization would help them build a two-room shelter, and, if not, Afghans would be provided with sufficient cash to build a one-room house (Wyckoff 2016). The NRC shelter assistance program provided cash assistance in installments for shelter, and the cash grant for each unit was USD1200 in 2012 (MGSOG and Samuel Hall 2012; Wyckoff 2016).

A published evaluation report on these programs showed that Afghan households had to contribute between USD285 and USD977 to be able to finish the UNHCR mud houses, and construction periods usually took more than the planned 2 months (MGSOG and Samuel Hall 2012). Moreover, this report showed that NRC cash grants could only cover $50 \%$ of the required funding for a complete shelter (MGSOG and Samuel Hall 2012). More importantly, only returnees with access to land could benefit from these programs, and for many returnees, the two- or one-room houses offered could not satisfy the minimum standard of per capita covered living area (MGSOG and Samuel Hall 2012). The UNHCR shelter assistance program, however, changed after 2013. The progress report under the framework of the Solutions Strategy shows that since the initiation of this program, over 3000 new shelter units were built for over 18,000 returnees in Afghanistan (UNHCR 2015b). Moreover, this progress report showcases that UNHCR, NRC, and United Nations Human Settlements Programme (UNHabitat) have been providing cash assistances for returnees to cover rents (UNHCR 2015b). 
The Information, Counselling, and Legal Assistance (ICLA) program of NRC is another initiative that helps returnees with access to shelter. Many Afghans who owned land in the past lived in exile for decades; during this period, various groups in power seized properties and re-distributed lands in the absence of a national and unified law (Macdonald 2011). Consequently, many returnees have found their homes destroyed or their lands occupied and remained unable to solve a dispute over a property with multiple layers of seizure or occupation (Macdonald 2011; Schmeidl 2009). Under the ICLA, NRC helps these returnees realize and dispute their property rights (Montygierd-Loyba et al. 2014). However, the scale of the program is too small to solve systematic gaps in Afghanistan. For instance, the country lacks formal documentation system for land ownership, and the traditional justice system has bias and often favors families in power (Macdonald 2011; Montygierd-Loyba et al. 2014; Roe 2008).

\section{Discussion and conclusion}

In this study, we only reviewed refugees' and returnees' access to minimum required covered living area and their access to a private latrine, kitchen, electricity, and piped water. It is worth mentioning that solving shelter problems for refugees or returnees requires a holistic approach, and the minimum discussed standards cannot guarantee successful reintegration or stability in the absence of other basic needs. The five reviewed indicators in this study are simply a minimum baseline for shelter, and comprehensive needs of refugees and returnees should be taken into consideration while addressing displacement.

Study findings show that access to the reviewed minimum standards of shelter could be a challenge for Afghan returnees. The living conditions of some Afghan returnees are so dire that their lives can be put at risk (Simpson et al. 2017). As stated by Afghan returnees themselves, shelter is their most important need and an essential element in their reintegration into Afghan society (Assessment Capacities Project 2016). It is estimated that 900,000 people will need shelter assistance in Afghanistan in 2018 and among them are 440,000 returnees (United States Agency for International Development [USAID] 2017). The literature suggests that lack of access to a durable shelter is one of the main reasons for the secondary displacement of Afghan returnees (Abbasi-Shavazi et al. 2005; Barr and Sanei 2013; Macdonald 2011; Schmeidl 2009; Milani 2006; Simpson et al. 2017). Estimates show that on average around $15 \%$ of the registered returnees in Afghanistan are forced to secondary displacement (UNHCR 2012). Afghan returnees who are forced to secondary displacement may stay with the borders of Afghanistan or may decide to pass international borders once more in search of protection.
Afghan returnees who are forced into secondary displacement and remain within the borders of Afghanistan join the mushrooming population of IDPs. Population of IDPs in Afghanistan increased drastically between 2012 and 2016, partly due to increased population of returnees (Samuel Hall et al. 2018). More than one in every 35 Afghans was an IDP in 2016 (Ahmadi and Lakhani 2016). In 2018, IDP population reached 1.5 million (International Displacement Monitoring Center [IDMC] 2018). Afghan IDPs live in some of the country's worst conditions, lacking access to basic needs such as food, education, healthcare, and housing (Samuel Hall et al. 2018; Simpson et al. 2017). Three quarters of IDPs in Afghanistan do not receive any assistance and resort to harmful coping strategies including sending children out to work and skipping meals (Samuel Hall et al. 2018). According to a report by Samuel Hall, NRC, and IDMC (2018), over $20 \%$ of returnee-IDPs rely on child labor.

Afghan returnees who are forced into secondary displacement may pass international borders, and higher access levels to shelter and minimum standards of living for refugees in Iran could be an important pull factor to encourage their decision. However, Afghans who come back to Iran after repatriation might not be able to qualify for refugee status once more and could be forced to live as undocumented Afghans (Abbasi-Shavazi et al. 2005; Barr and Sanei 2013; Milani 2006; Schmeidl 2009). In this context, repatriation is creating a vicious circle adding to the vulnerability of Afghans instead of creating a solution to end their displacement. Our review shows that heavy investments in repatriation programs and Iran's new policies encouraged and sometimes forced Afghans to leave their rather stable living situations in Iran, returning to sub-standard housing or secondary displacement in Afghanistan. While the return is called "voluntary," often Afghans have minimal input in the decision-making process and are provided with little information about what they can expect after their return (Majidi 2017). For younger generations born and raised in Iran without ties in Afghanistan, repatriation is not considered a return to home, but a displacement to a new country. Furthermore, return is commonly perceived as a failure, and stigma associated with it can further isolate the returnees (Majidi 2017). These factors can make coping with the challenges of return difficult for Afghans, especially in the absence of a comprehensive repatriation plan to assure access to minimum standards of living after return. Our findings show that policies to encourage repatriation are not well supported to assure successful return. Moreover, our review found lack of coordination between different sectors resulting in failure of assistance programs such as land allocation.

The actions of UNHCR in promoting voluntary repatriation as a durable solution, in the absence of decent 
housing in Afghanistan, creates vulnerability and forces Afghans to languish in limbo. Moreover, changes in Iran's policy to pressure Afghans to repatriate are equivalent to denying refugees a say in their own future. Although Afghans are temporary refugees in Iran, and will not receive citizenship even if they are born in this country or despite years of habitual residency, they may prefer their rather stable housing in exile over struggling to find a decent shelter in Afghanistan (Barr and Sanei 2013; Garakani 2009). In this context, our study provides valuable lessons learned and implications for other groups of refugees. As conflict in Syria enters its seventh year, hosting fatigue could happen in the future in Syrian refugees' host countries. Therefore, return-focused refugee management policies might be hastily enforced. This enforcement could put refugees at risk of secondary displacement. High levels of collaboration between different sectors is required to assure, access to land, shelter, security, livelihood, and basic standards of living for a successful repatriation of returnees. Lessons learned from this study encourage stakeholders to note that secondary displacement after repatriation could cause harm for all parties.

\section{Recommendations}

The findings of this study call for a reevaluation of voluntary repatriation as a durable solution in the absence of a decent shelter in Afghanistan. In this context, there is a need for a systematic research on returnees and secondary displacement in Afghanistan. Moreover, long-term planning is required to enhance Afghanistan's capacity to properly accommodate returnees. Years of conflict have crippled Afghanistan's vital organizations, and large repatriation programs have placed pressure on local communities. Furthermore, higher levels of burden sharing are required in Afghanistan's infrastructure to expand housing and shelters in the country for returnees. For instance, investment is required to develop new houses in Afghanistan, reducing the pressure in the housing market and providing affordable accommodation for returnees. There is also a need to develop a centralized land ownership system to prevent land disputes.

In the meantime, as part of the repatriation programs planning should take place to assure decent housing for any returnee. This could be a pull factor facilitating the repatriation of Afghans. Despite evidence of better outcomes among returnees who received assistance before departure, current support for Afghan returnees is provided only after return (Majidi 2017). In this context, further coordination is required between the international organizations, donors, local stakeholders in Afghanistan, and governments of host countries. Addressing returnees' shelter needs require collaboration between different sectors to assure access to land, shelter, security, livelihood opportunities, and basic standards of living. In this context, further attention should be given to livelihood opportunities and minimum standards of living in the allocated lands under the LAS.

Moreover, there is a need for more regulation in the housing market in Afghanistan to prevent arbitrary increases in rent costs. Reports indicate that landlords in Afghanistan see the influx of returnees as an opportunity to raise rents (Samuel Hall et al. 2018). Provided cash assistances for covering rent by UNHCR, NRC, or UN-Habitat could be released directly to landlords with a guarantee for fixed rates in longer periods of time. In short-term, prefabricated transitional shelters could be used for immediate accommodation of returnees. This accommodation could be critical within the first month after return, when Afghans seek protection and assess their ability to integrate or move again (Majidi 2017). Pre-fabricated shelters such as RHU can be shipped in two flat boxes (dimensions of $196 \mathrm{~cm}$ in length, $110 \mathrm{~cm}$ in width, and $24 \mathrm{~cm}$ in height) weighing $160 \mathrm{~kg}$ and assembled by four trained people in 5 to $6 \mathrm{~h}$. A unit of RHU provides $17.5 \mathrm{~m}^{2}$ of sturdy covered floor area with the durability of 1.5 to 3 years (UNHCR n.d.).

\section{Limitation}

The dataset utilized in this study to assess the housing situation of Afghans in Iran was collected from a non-probability sample in 2011. Therefore, the results might not be representative of the entire population of Afghans in Iran and their current situation. Moreover, in the absence of a comprehensive study on the housing situation of Afghan returnees, we relied on existing reports, news, and studies. Consequently, our assessment about the housing situation of Afghan returnees might not be the best representation of the current housing situation.

\section{Abbreviations \\ BAFIA: Bureau for Aliens and Foreign Immigrants Affairs; IDMC: International Displacement Monitoring Center; IDP: Internally Displaced People; \\ IOM: International Organization for Migration; LAS: Land Allocation Scheme; MGSOG: The Maastricht Graduate School of Governance; NRC: Norwegian Refugee Council; OEF: Operation Enduring Freedom; RHU: Refugee Housing Unit; SIGAR: Special Inspector General for Afghanistan Reconstruction; UN- Habitat: United Nations Human Settlements Programme; UNHCR: United Nations High Commissioner for Refugees; UNICEF: United Nations Children's Fund; UNOCHA: United Nations Office for the Coordination of Humanitarian Affairs; USAID: United States Agency for International Development; WHO: World Health Organization}

\section{Availability of data and materials}

Interested researchers can contact the first author for data requests.

\section{Authors' contributions}

MN and SP conceived the idea of this study. MN conducted the systematic search, calculated the descriptive statistical analyses, and drafted the paper. MP and PS provided major contributions to the final manuscript. All authors read and approved the final manuscript. 


\section{Competing interests}

The authors declare that they have no competing interests.

\section{Publisher's Note}

Springer Nature remains neutral with regard to jurisdictional claims in published maps and institutional affiliations.

\section{Author details}

${ }^{1}$ School of Social Work, Robert Stempel College of Public Health and Social Work, Florida International University, Miami, USA. ${ }^{2}$ Department of Architecture, College of Communication, Architecture + The Arts Florida International University, Miami, USA.

Received: 2 March 2018 Accepted: 27 July 2018

Published online: 09 October 2018

\section{References}

Abbasi-Shavazi M, Glazebrook D, Jamshidiha G, Mahmoudian H, Sadeghi R (2005) Return to Afghanistan? A study of Afghans living in Iran. Afghanistan Research and Evaluation Unit, Kabul http://www.academia.edu/7932338/ RETURN_TO_AFGHANISTAN_A_Study_of_Afghans_Living_in_Tehran. Accessed 18 Dec 2017

Abbasi-Shavazi M, Glazebrook D, Jamshidiha G, Mahmoudian H, Sadeghi R (2008) Second-generation Afghans in Iran: integration, identity and return. Afghanistan Research and Evaluation Unit, Kabul https://areu.org.af/wpcontent/uploads/2016/01/823E-Second-Generation-Afghans-in-Iran-CS-2008. pdf. Accessed 18 Dec 2017.

Adelkhah F, Olszewska Z (2007) The Iranian Afghans. Iranian Studies 40:137-165. https://doi.org/10.1080/00210860701269519

Ahmadi B, Lakhani S (2016) The forced return of Afghan refugees and implications for stability. PeaceBrief 199:1-5

Assessment Capacities Project. (2016) ACAPS Briefing Note: Undocumented returnees in Afghanistan. https://reliefweb.int/report/afghanistan/afghanistanacaps-briefing-note-undocumented-returnees-pakistan-27-august-2016. Accessed 18 Dec 2017.

Ahmadinejad, M (2011) Multidimensional Poverty and Inequality among Afghan Refugees: The Case of Afghan Refugees Residing in Selected Areas of Iran (Master's Thesis) Alzahra University. https://ganj-old.irandoc.ac.ir/articles/ 527076. Accessed 8 August 2018.

Azizi S, Hosseini SE, Basavaraju C (2017) Evaluating performance of Iran's domestic laws on effective protection of refugees. Journal of International Academic Research for Multidisciplinary 5:70-89

Babister E, Kelman I (2002) The emergency shelter process with application to case studies in Macedonia and Afghanistan. The Martin Centre University of Cambridge, Cambridge http://shelterpakistan.org/media/1096/shelter_case_ studies_2002.pdf. Accessed 18 Dec 2017

Barr, H., Sanei, F. (2013) Unwelcome guests: Iran's violation of Afghan refugee and migrant rights. Human Rights Watch, NY. https://www.hrw.org/report/ 2013/11/20/unwelcome-guests/irans-violation-afghan-refugee-and-migrantrights. Accessed 18 Dec 2017.

Crea TM, Loughry M, O'halloran C, Flannery GJ (2017) Environmental risk: Urban refugees' struggles to build livelihoods in South Africa. International Social Work 60:667-682

Ender MG (2010) War causes and consequences. Contemporary Sociology: A Journal of Reviews 39:399-402. https://doi.org/10.1177/0094306110373236a

Farrokhi, F., Rahmati, M. H. (2010).The Driving Forces of Iran's Baby Boom https:// pdfs.semanticscholar.org/26ed/983bb39d68c10d6ac0b4a9ccd9570c135ec6. pdf. /. Accessed 12 July 2018.

Garakani, T. (2009) Place-making in the margins: A case study of Afghan refugees in Iran (1980-2001) Columbia University. https://search-proquest-com.ezproxy.fiu. edu/docview/304865350?pq-origsite=gscholar. Accessed 8 Aug 2018

International Displacement Monitoring Center (IDMC) (2018) Afghanistan http:// www.internal-displacement.org/countries/afghanistan/. Accessed 4 May 2018

International Organization for Migration (IOM) (2016) Undocumented Afghan returnees appeal. International Organization for Migration, Kabul https:// www.iom.int/sites/default/files/country_appeal/file/IOM-AfghanistanReturnee-Appeal-Sep-Dec-2016.pdf. Accessed 18 Dec 2017

International Organization for Migration (IOM) (2017) Baseline mobility assessment summary results. International Organization for Migration, Kabul https://afghanistan.iom.int/sites/default/files/Reports/iom_dtm_afg_baseline_ assessment_round1_summary_results.pdf. Accessed 18 Dec 2017
Jacobsen K (2005) The economic life of refugees. Kumarian Press, Bloomfield Kamminga J, Zaki A (2018) Returning to fragility, exploring the link between conflict and returnees in Afghanistan. Oxfam, Oxford https://reliefweb.int/ sites/reliefweb.int/files/resources/rr-returning-fragility-afghanistan-310118-en. pdf. Accessed 4 May 2018

Kent, S., Ahmed, S., Naqibullah. (2017) Labour and housing market systems in Nangarhar. Oxfam and Assistance for Health, Education, and Development Afghanistan (AHEAD), Kabul http://www.baag.org.uk/sites/www.baag.org.uk/ files/resources/attachments/Oxfam_EMMA_Nangarhar_Report_May_2017.pdf. Accessed 18 Dec 2017

Koepke B (2011) The situation of afghans in the Islamic republic of Iran nine years after the overthrow of the Taliban regime in Afghanistan. Middle East Institute: Refugee Cooperation 4:1-13

Landinfo (2012) Report, Afghan Citizens in Iran. Landinfo, Storgata https:// landinfo.no/asset/2063/1/2063_1.pdf. Accessed 4 May 2018

Loschmann C, Parsons CR, Siegel M (2015) Does shelter assistance reduce poverty in Afghanistan? World Development 74:305-322

Macdonald I (2011) Landlessness and insecurity: Obstacles to reintegration in Afghanistan Middle East Institue-Fondation Pour La Recherche Stratgique, Washington

Majidi N (2013) Home sweet home! repatriation, reintegration and land allocation in Afghanistan. Revue Des Mondes Musulmans Et De La Mditerrane 133:207-225

Majidi N (2017) From forced migration to forced returns in Afghanistan: Policy and program implementation. Migration Policy Institute, Washington https:// www.migrationpolicy.org/research/forced-migration-forced-returnsafghanistan. Accessed 18 Dec 2017

Marchand K, Siegel M, Kuschminder K, Majidi N, Vanore M, Buil C (2014) Afghanistan migration profile. International Organization for Migration, Kabul https://afghanistan.iom.int/sites/default/files/Reports/afghanistan_migration_ profile.pdf. Accessed 18 Dece 2017

Margesson R (2007) Afghan refugees: current status and prospects. Congressional Research Service, Washington https://fas.org/sgp/crs/row/RL33851.pdf. Accessed 18 December 2017

Milani MM (2006) Iran's policy towards Afghanistan. The Middle East Journal 60:235-256

Montygierd-Loyba, H., Aiken, M., Adeyemi, F., Hassrat, H., Franzi, A., Alimi, M. (2014) Norwegian refugee council Afghanistan information, counseling and legal assistance. https://www.nrc.no/globalassets/pdf/evaluations/ afghanistan\%2D\%2D-information-counselling-and-legal-assistance-iclaprogramme-evaluation.pdf. Accessed 18 Dec 2017.

Moravej M (2014) Cross-cultural adaptation among young Afghan refugees returning from Iran to Afghanistan. University of Ottawa, Dissertation

Norwegian Refugee Council (NRC) (2015) NRC Afghanistan- fact sheet. https:// www.flyktninghjelpen.no/globalassets/pdf/fact-sheets/afghanistan-fact-sheetjuly-2015.pdf. Accessed 18 Dec 2017.

NRC 2017 Norwegian Refugee Council's Country programme in Afghanistan: Factsheet Sept 2017 https://www.nrc.no/globalassets/pdf/fact-sheets/2017/ afghanistan/july/nrc-country-factsheet-afghanistan.pdf. Accessed 1 August 2018

Qadeem M (2005) Chapter 1, Afghanistan: the long way home. In: Banerjee P, Chaudhury SBR, Das SK (eds) Internal displacement in south Asia: The relevance of the UN's guiding principles. Sage, New Delhi, pp 30-61

Rajaee B (2000) The politics of refugee policy in post-revolutionary Iran. The Middle East Journal 54:44-63

Rao S, Turkstra J (2014) Enhancing security of land tenure for IDPs. Forced Migration Review 46:15-18

Roe A (2008) Water management, livestock and the opium economy: Natural resources management, farming systems and rural livelihoods. Afghanistan Research and Evaluation Unit, Kabul https://reliefweb.int/sites/reliefweb.int/ files/resources/855A159D714CBB77492574F500275D8C-Full_Report.pdf. Accessed 18 Dec 2017

Rostami-Povey E (2008) Afghan women's resistance and struggle in Afghanistan and diasporic communities, 2004-2005. School of Oriental and African Studies, University of London, London doi:RES-000-22-0762

Ruiz HA (2004) Afghanistan: Conflict and displacement 1978 to 2001. Forced Migration Review 13:8-13

Samuel Hall, NRC, IDMC (2018) Escaping war: where to next? A research study on the challenges of IDP protection in Afghanistan. http://samuelhall.org/wp-content/ uploads/2018/01/NRC-IDP_Afghanistan_FINAL.pdf. Accessed 18 Dec 2017.

Scalettaris G (2010) Refugees or Migrants? The UNHCR's Comprehensive Approach to Afghan Mobility into Iran and Pakistan. In: The Politics of International Migration Management. Palgrave Macmillan, London, pp 252-270

Schmeidl S (2009) Repatriation to Afghanistan: durable solution or responsibility shifting? Forced Migration Review 33:20-22 
Sharp TW, Burkle FM Jr, Vaughn AF, Chotani R, Brennan RJ (2002) Challenges and opportunities for humanitarian relief in Afghanistan. Clinical Infectious Diseases 34(Supplement_5):S228

Simpson G, ljaz S, Shuja A, Frelick B, Gossman P, Sunderland J et al (2017) Pakistan coercion, UN complicity: The mass forced return of Afghan refugees. Human Rights Watch, New York https://www.hrw.org/ sites/default/files/report_pdf/pakistan0217_web.pdf. Accessed 18 Dec 2017

Special Inspector General for Afghanistan Reconstruction (SIGAR) (2015) Afghan refugees and returnees: Corruption and lack of afghan ministerial capacity have prevented implementation of a long-term refugee strategy (Audit Report No. SIGAR 15-83). https://www.sigar.mil/pdf/audits/SIGAR-15-83-AR. pdf. Accessed 18 Dec 2017.

StataCorp LP (2015) STATA 12 [Computer software]. StataCorp LP, College Station Statistical Center of Iran (2010) Income and expenditure form. Statistical Center of Iran, Tehran

The Global Economy (2018) Afghanistan: Access to drinking water, urban https:// www.theglobaleconomy.com/Afghanistan/drinking_water_urban/. Accessed 4 May 2018.

The International Bank for Reconstruction and Development (2017) Afghanistan's Forced Displacement Legal \& Policy Framework Assessment. The International Bank for Reconstruction and Development / The World Bank Group, Washington http://documents. worldbank.org/curated/en/117261515563099980/pdf/122556-WPAfghanistanForcedDisplacementLegalandPolicyFrameworKAssessmentFPUBLIC.pdf. Accessed 4 May 2018

The Maastricht Graduate School of Governance (MGSOG), Samuel Hall (2012) Evaluation of the UNHCR shelter assistance programme. http://samuelhall. org/REPORTS/UNHCR\%20Shelter\%20Assistance\%20Programme\%20Evaluation. pdf. Accessed 18 Dec 2017

The Sphere Project (2011) Chapter 4: minimum standards in shelter, settlement and non-food items. In: Darcy J, Picard M, Bishop J, Smith C, Klynman Y, Mierop ESV et al (eds) Humanitarian charter and minimum standards. Belmont Press Ltd., Northampton, pp 203-248 http://www.ifrc.org/PageFiles/ 95884/D.01.02.a.\%20SPHERE\%20Chap.\%204-\%20shelter\%20and\%20NFIs_ \%20English.pdf. Accessed 18 Dec 2017

The World Bank (2017) Access to electricity (\% of population). https://data. worldbank.org/indicator/EG.ELC.ACCS.ZS. Accessed 18 Dec 2017.

UNHCR (2014) Solution Strategy for Afghan Refugees to Support Voluntary Repatriation, Sustainable Reintegration and Assistance to Host Countries, Portfolio of Projects, Islamic Republic of Iran. http://www.unhcr.org/ 561786e29.pdf. Accessed 4 May 2018.

UNHCR (2015a) Solution Strategy for Afghan Refugees to Support Voluntary Repatriation, Sustainable Reintegration and Assistance to Host Countries, Portfolio of Projects2015-2016, Islamic Republic of Iran. http://www.unhcr. org/539ab62a9.pdf. Accessed 4 May 2018.

UNHCR (2015b) Solution Strategy for Afghan Refugees to Support Voluntary Repatriation, Sustainable Reintegration and Assistance to Host Countries, Portfolio of Projects 2015-2016, Islamic Republic of Afghanistan. http://www. unhcr.org/539ab7f79.pdf. Accessed 4 May 2018.

UNHCR (2016a) Chapter 7: Solutions for refugees in The 10-point plan in action. UNHCR, Geneva, pp 184-206 http://www.unhcr.org/50a4c17f9.pdf. Accessed 18 Dec 2017

UNHCR (2016b) Shelter Design Catalog. UNHCR, Geneva https://cms.emergency. unhcr.org/documents/11982/57181/Shelter+Design+Catalogue+January +2016/a891fdb2-4ef9-42d9-bfof-c12002b3652e

UNHCR (2017a) Global trends: Forced displacement in 2016. UNHCR, Geneva http://www.unhcr.org/5943e8a34. Accessed 18 Dec 2017

UNHCR (2017b) UNHCR Afghanistan Voluntary Repatriation Monthly Report, June 2017. UNHCR, Kabul https://data2.unhcr.org/en/documents/download/59085. Accessed 4 May 2018

UNHCR (2017c). Update on UNHCR's operations in Asia and the Pacific, Executive Committee of the High Commissioner's Programme, Standing Committee, 68th meeting. http://www.unhcr.org/58ca4ade7.pdf. Accessed 14 July 2018

UNHCR (n.d.) Refugee Housing Unit-RHU. UNHCR Shelter and Settlement Section, Geneva https://cms.emergency.unhcr.org/documents/11982/57181/ Refugee+Housing+Unit+Fact+Sheet/7b4fce59-0af2-45ea-9386-7fde249d2fe9. Accessed 18 Dec 2017

United Nations High Commissioner for Refugees [UNHCR] (2012) Internationa Conference on the Solution Strategy for Afghan Refugees to Support
Voluntary Repatriation, Sustainable Reintegration and Assistance to Host Countries https://reliefweb.int/sites/reliefweb.int/files/resources/62341.pdf. Accessed 4 May 2018.

United States Agency for International Development [USAID] (2017) Afghanistan - Complex Emergency, Fact Sheet \#1, Fiscal Year (FY) 2018 https://www. usaid.gov/sites/default/files/documents/1866/afghanistan_ce_fs01_12-272017.pdf. Accessed 4 May 2018.

WHO, UNICEF (2017) Progress on drinking water, sanitation and hygiene: 2017 update and SDG baselines file://Users/mitranaseh/Downloads/JMP-2017report-final\%20(1).pdf. Accessed 1 August 2018

Wyckoff, M. E. (2016). Securing tenure in shelter operations, guidance for humanitarian response. https://www.sheltercluster.org/sites/default/files/ docs/nrc_shelter_tenure_guidance_external.pdf. Accessed 18 Dec 2017.

\section{Submit your manuscript to a SpringerOpen ${ }^{\circ}$ journal and benefit from:}

- Convenient online submission

- Rigorous peer review

- Open access: articles freely available online

- High visibility within the field

- Retaining the copyright to your article

Submit your next manuscript at $\boldsymbol{\nabla}$ springeropen.com 